\title{
Transforming Inclusive Education: Nine Tips to Enhance School Leaders' Ability to Effectively Lead Inclusive Special Education Programs
}

\author{
Cammy Romanuck Murphy \\ Saskatoon, Saskatchewan, Canada
}

Principals and assistant principals, collectively referred to as school leaders, play instrumental roles in ensuring the success of inclusive special education in the schools they oversee. However, school leaders continually report they lack the knowledge and skills to effectively oversee quality inclusive special education programs. There are very few training programs available to school leaders that focus on leading inclusive special education programs. Therefore, the purpose of this article is to provide school leaders with nine tips, along with 11 immediately implementable practical strategies, to improve upon the inclusive special education programs in their schools. Topics include pertinent definitions, laws, and concepts associated with inclusion; models of coteaching; transformational leadership theory and traits; roles and responsibilities of school leaders in inclusive education programs; and practical strategies to implement to improve upon current inclusive education practices. This article is designed to be used with emerging, new, and experienced school leaders.

Keywords: school leaders, principals, inclusive education, inclusion, transformational leadership, special education

\section{Introduction}

Following the reauthorization of the Individuals With Disabilities Education Improvement Act (IDEA) of 2004, combined with research supporting the benefits of inclusive educational models, school districts have been prompted to establish inclusive special education programming for students with disabilities (Bublitz, 2016; Carson, 2015; IDEA, 2004; Kurth \& Mastergeorge, 2010; Waldron \& McLeskey, 1998). Prior to the reauthorization of IDEA (2004), special education was typically the responsibility of district administrators and special education teachers. However, after the reauthorization of IDEA (2004) and with an increased focus on inclusive education for students with disabilities, principals and assistant principals, also collectively referred to as school leaders, have become largely responsible for overseeing and implementing inclusive education programs in their schools (Cobb, 2015; Lashley, 2007).

According to Stevenson-Jacobson and Hilton (2006), principals spend between $36 \%$ and $58 \%$ of their day addressing special education matters. Some of their responsibilities related to inclusive special education include student discipline, attending meetings, addressing parental concerns, and completing teacher evaluations (Lynch, 2012). In addition, they are responsible for creating a shared vision and mission for the school and district; promoting a positive culture and climate for learning; providing instructional leadership and professional development; collaborating with other stakeholders; determining student placement; and monitoring and evaluating educational programs (Cobb, 2015; Marzano, Waters, \& McNulty, 2005; Nicolas, 2015).

Please address queries to: Cammy Romanuck Murphy, Independent Researcher, Saskatoon, Saskatchewan, Canada. Email: cdromanuck@gmail.com 
Unquestionably, school leaders play instrumental roles in ensuring the success of inclusive special education programs in the districts they oversee. Moreover, one of the largest indicators of successful inclusive education programs is school leaders' positive attitudes toward inclusion (Bublitz, 2016; Chandler, 2015; Hack, 2014). With an increasing focus on providing quality and legally compliant inclusive special education services across the nation, it is more important than ever that school leaders understand their roles and responsibilities associated with inclusion.

However, even now, 14 years after the reauthorization of IDEA (2004), school leaders continually report they lack the knowledge and skills to effectively oversee quality inclusive special education programs in their districts (Abernathy, 2012; Ball \& Green, 2014; Praisner, 2003; Williams, 2015). Furthermore, despite the laws that influence inclusive special education and the myriad of benefits inclusive education provides to all students, the degree of implementation of inclusive education programs continues to vary from state to state and from district to district (Salisbury, 2006). Without adequate training, role clarity, and a thorough understanding of inclusive education programs, school leaders cannot be expected to perform effectively as special education leaders.

\section{The Purpose of This Article}

There are very few training programs available to school leaders that focus on leading inclusive special education programs. Therefore, the purpose of this article is to provide school leaders with knowledge, skills, and practical strategies to sustain and improve upon the inclusive special education programs in their schools through the framework of transformational leadership theory. Topics include pertinent definitions, laws, and concepts associated with inclusion; models of coteaching; transformational leadership theory and traits; roles and responsibilities of school leaders in inclusive education programs; and practical strategies to implement to improve upon current inclusive education practices. This article is designed to be used with emerging, new, and experienced school leaders. Nine tips, along with 11 immediately implementable practical strategies to improve or sustain effective inclusive education practices, are provided.

\section{Tip 1: Review Important Definitions, Concepts, and Laws}

According to the 2011-2012 Schools and Staffing Survey, the vast majority of K-12 principals have teaching experience prior to accepting a leadership role (U.S. Department of Education, 2013). However, many school leaders have indicated they have limited experience and a lack of training in working with students with disabilities in inclusive settings (Abernathy, 2012; Ball \& Green, 2014; Praisner, 2003; Williams, 2015). It is crucial that school leaders have an understanding of key special education concepts to ensure the successful implementation of inclusive programs in the schools they oversee.

Additionally, under federal law, public schools are required to provide all students with a free and appropriate public education, regardless of special needs. If school districts do no adhere to IDEA (2004) guidelines, this opens the doors for litigation. Due process for special education matters is very common across the United States. Schools leaders can protect their school and students by ensuring they are in compliance with IDEA guidelines. On the following pages, the most important definitions, concepts, and laws with which school leaders should be familiar are outlined.

\section{Inclusion}

Inclusion refers to the provision of services to students with disabilities, including those with severe impairments, in their neighborhood school, in age-appropriate general education classes with the necessary support services and supplementary aids (for the child and the teacher) both to assure the child's success—academic, behavioral, and social—and to prepare the child to participate as a full 
and contributing member of the society (The National Center on Educational Restructuring and Inclusion, 1994, p. 3).

\section{Individuals With Disabilities Education Improvement Act (IDEA)}

The IDEA of 2004 is a federal law that requires schools to provide qualified students with disabilities with a free and appropriate public education that is tailored to their individual needs as outlined in the students' individualized education plans (IEPs).

\section{Free and Appropriate Public Education}

A free education ensures "recipients operating federally funded programs must provide education and related services free of charge to students with disabilities and their parents or guardians" (U.S. Department of Education, 2010, para. 8). An appropriate education for students with disabilities ensures "education services [are] designed to meet the individual education needs of students with disabilities as adequately as the needs of nondisabled students are met" (U.S. Department of Education, 2010, para. 3).

\section{Individualized Education Plan}

An IEP is a

written statement for each child with a disability that is developed, reviewed, and revised in a meeting... that must include: a statement of the child's present levels of academic achievement and functional performance [and] a statement of measurable annual goals. (IDEA, 2004, p. 1)

\section{Least Restrictive Environment}

The IDEA stated,

To the maximum extent appropriate, children with disabilities, including children in public or private institutions or other care facilities, are educated with children who are not disabled, and special classes, separate schooling, or other removal of children with disabilities from the regular educational environment occurs only when the nature or severity of the disability of a child is such that education in regular classes with the use of supplementary aids and services cannot be achieved satisfactorily. (§ 612 [a][5], para. 1)

\section{Tip 2: Take Time to Understand the Benefits of Inclusive Education}

Although it is important to understand and adhere to the legal implications of special education, it is also important to understand the many other reasons schools should adhere to a philosophy of inclusion. When done purposefully, inclusive education is more effective for all students than traditional models (IDEA, 2004). Research indicates there are many benefits of inclusive education for both students with and without disabilities. Some of these benefits include social/emotional growth for students with and without disabilities; increased academic outcomes for students with and without disabilities; strong relationships; a heightened acceptance of human diversity by students without disabilities; enhanced self-image for students with disabilities; increased empathy, caring, and understanding; peer models for students with disabilities; and preparation for the "real world" for all students (Garrick Duhaney \& Salend, 2000; Ko \& Boswell, 2013; Romanuck Murphy, 2017; Yssel, Engelbrecht, Oswald, Eloff, \& Swart, 2007). 
School leaders' perceptions toward inclusion affect teacher, parent, and student attitudes toward inclusion. A school leader's perceptions toward inclusion also affect school culture and climate, student placement decisions, and a shared belief that all students can and will learn (Cobb, 2015; Hack, 2014; Lynch, 2012; Urton, Wilbert, \& Hennemann, 2014). Therefore, it is imperative school leaders reflect upon their perceptions toward inclusion and understand the benefits of inclusive education for both students with and without disabilities.

\section{Tip 3: Review Coteaching Models of Instruction}

Teachers in inclusive schools plan and teach collaboratively. They make decisions about service delivery based on the individualized needs of students with disabilities. They also consider the most effective methods of instruction to promote overall student learning. Coteaching, when done well, is a very effective way of meeting the needs of students with and without disabilities in inclusive settings (Harpell \& Andrews, 2010).

Though many school leaders may be familiar with coteaching, it is important to review best practices in coteaching strategies to ensure school leaders know what to look for when completing classroom observations in inclusive classrooms. School leaders are ultimately responsible for providing professional development, mentorship, and evaluation feedback to teachers (Earley \& Bubb, 2004; Lynch, 2012). Therefore, school leaders must be intimately familiar with coteaching strategies so they can provide teachers with guidance and feedback for best practices in educating students with disabilities in inclusive settings. Below, the six models of coteaching are outlined. The following models of coteaching, including suggested school leader observations, are adapted from documentation obtained from the Papillion La Vista Community Schools (2017).

\section{One Teach, One Assist}

In the one teach, one assist model of coteaching, one teacher teaches the lesson, and the other teacher supports individual students within the whole group. School leaders should look for evidence that the lesson was planned collaboratively. In this model, the assisting teacher should provide ongoing monitoring of student performance throughout the lesson. This can be done by taking data on a student's IEP goals, asking clarifying questions, or conducting informal assessments. This model of instruction may be used in conjunction with other models.

\section{One Teach, One Observe}

One teach, one observe refers to one teacher teaching the lesson and the other teacher observing the lesson, typically while collecting data. In this model of instruction, school leaders should observe both teachers. One teacher should be providing effective instruction, and the other teacher should be taking notes and recording data, as appropriate. This model of instruction should be used sparingly and only for a specific purpose.

\section{Station Teaching}

Station teaching requires teachers to divide students into small groups. Each teacher teaches a different group of students. There may also be independent stations. The groups of students rotate through each station. School leaders should look for evidence of collaborative planning in this model of coteaching. Additionally, school leaders should observe a heterogeneous classroom with flexible groupings of students. Lessons should incorporate student participation through discussion and activities. This model of coteaching may be used frequently if station materials can be taught independently and the sequence of instruction is unimportant. 


\title{
Parallel Teaching
}

When parallel teaching, two teachers are both teaching the same lesson, but students are divided into two groups. This type of instruction requires collaborative planning. School leaders should observe equivalent instruction in both groups with modifications and accommodations to support IEP goals, as appropriate. There should be active participation from all students in both groups.

\begin{abstract}
Alternative Teaching
Alternative teaching refers to one teacher teaching a large group and a second teacher working with a smaller group of students for a specific purpose. As with other models, alternative teaching requires collaborative planning. School leaders should observe small group instruction used for specific purposes such as skills testing, enrichment, remediation, or preteaching. The two teachers typically alternate leading small groups.
\end{abstract}

\section{Team Teaching}

Lastly, team teaching refers to two teachers planning and instructing a lesson equally. Collaborative planning for team teaching models is imperative. School leaders should look for evidence of shared instruction and assessment responsibilities. Additionally, a variety of materials and resources to meet all students' needs should be used.

\section{Tip 4: Identify the Strengths and Needs of Coteaching Models in Your School}

It is crucial school leaders have a strong grasp on what effective inclusive instructional practices look like. After reviewing the six models of coteaching, school leaders may reflect upon current practices in the schools they oversee. Guiding questions may include the following: (a) "What models of coteaching have you observed in your school?" (b) "What is a coteaching area of need in your school?" (c) "What is one coteaching strength in your school?" and (d) "What are the barriers that impede your teachers' ability to effectively coteach in inclusive settings?"

\section{Tip 5: Understand Your Role in Inclusive Education}

Once school leaders have a firm grasp on best practices in inclusive education instruction, including coteaching models, and the strengths and needs of instruction in their schools, they can offer guidance and seek out professional development that supports teachers to be effective in educating students with disabilities in inclusive settings. In addition to providing professional development to teachers, school leaders, as special education leaders, are responsible for creating a shared vision and mission for the school, promoting a positive culture and climate for learning, collaborating with other stakeholders, determining student placement, and monitoring and evaluating educational programs, including inclusive special education programs (Cobb, 2015; Marzano et al., 2005; Nicolas, 2015).

\section{Tip 6: Understand the Impact of Transformational Leadership on Inclusion}

Transformational leadership has been tied to the successful implementation of inclusive education programs in a variety of ways including creating a positive culture, increased teacher efficacy, and increased student achievement (Bonar, 2000; Lucas \& Wayne, 2003; Marks \& Louis, 1997; Zohar \& Tenne-Gazit, 2008). Transformational leaders enhance inclusive programs in their schools by effectively communicating their visions, overcoming obstacles, and encouraging others to do the same (Moman Basham, 2012). Transformational leaders lead with enthusiasm and passion, and others tend to follow these types of inspiring individuals (ChangingMinds.org, n.d.). The attitudes 
and values of transformational leaders motivate their followers to create common goals, which ultimately lead to successful outcomes (Tucker \& Russell, 2014). As outlined by Bass (1985), Table 1 shows the primary traits of transformational leaders.

Table 1. Traits of Transformational Leaders

\begin{tabular}{ll}
\hline Transformational Leadership Trait & Definition \\
\hline Individualized consideration & $\begin{array}{l}\text { One's ability to provide individualized one-on- } \\
\text { one support to others as needed }\end{array}$ \\
Inspirational motivation & $\begin{array}{l}\text { One's ability to inspire and motivate followers } \\
\text { by establishing a vision for learning that } \\
\text { coincides with the organization's mission }\end{array}$ \\
Leaders are respected and trusted within their \\
Idealized influence & $\begin{array}{l}\text { Onganizations } \\
\text { One's ability to continually motivate others to } \\
\text { explore new and creative ways of learning and } \\
\text { instructing }\end{array}$ \\
\hline
\end{tabular}

\section{Tip 7: Reflect on Transformational Leadership Traits Related to Your Role}

Transformational leaders inspire their followers. Their positive perceptions toward inclusive education affect teacher, parent, and student attitudes toward inclusion. School leaders' perceptions toward inclusion also impact their school's climate and culture, student placement decisions, and a shared belief that all students can and will learn (Cobb, 2015; Hack, 2014; Lynch, 2012; Urton et al., 2014). Table 2 aligns school leaders' roles and responsibilities as special education leaders with necessary transformational leadership traits.

Table 2. School Leaders' Responsibilities and Corresponding Transformational Leadership Traits

\begin{tabular}{|c|c|}
\hline Responsibility & Transformational Leadership Traits \\
\hline Creating a shared vision and mission & $\begin{array}{l}\text { Inspirational motivation, idealized influence, } \\
\text { intellectual stimulation }\end{array}$ \\
\hline Promoting a positive culture & $\begin{array}{l}\text { Individualized consideration, inspirational } \\
\text { motivation, idealized influence }\end{array}$ \\
\hline Collaboration & Inspirational motivation, idealized influence \\
\hline Student placement & $\begin{array}{l}\text { Individualized consideration, idealized } \\
\text { influence }\end{array}$ \\
\hline Monitoring and evaluating programs & $\begin{array}{l}\text { Individualized consideration, idealized } \\
\text { influence, intellectual stimulation }\end{array}$ \\
\hline $\begin{array}{l}\text { Instructional leadership and professional } \\
\text { development }\end{array}$ & $\begin{array}{l}\text { Individualized consideration, intellectual } \\
\text { stimulation }\end{array}$ \\
\hline
\end{tabular}

\section{Tip 8: Evaluate Strengths and Needs as Transformational Special Education Leaders}

All school leaders-whether employed by a district that is struggling to provide quality inclusive education services or one with a very strong inclusive special education program-would benefit from taking time to reflect on their strengths and needs as transformational special education leaders. One way to do this is by completing a short, self-reflective survey based on the comfort with their roles and responsibilities associated with inclusive special education programs (Figure 1). Next, school leaders should complete a short, self-reflective survey that incorporates principles of transformational leadership theory related to overseeing successful inclusive education programs 
(Figure 2). Through these surveys, school leaders can identify areas of strength and need related to special education leadership.

\begin{tabular}{|c|c|c|c|c|c|}
\hline \multirow{2}{*}{$\begin{array}{l}\text { Roles and Responsibilities } \\
\text { I have a vision for instruction and learning that } \\
\text { includes all students. }\end{array}$} & \multicolumn{5}{|c|}{$\begin{array}{c}\text { Key } \\
1 \text { = strongly disagree, } 2=\text { disagree, } 3=\text { neutral, } 4= \\
\text { agree, } 5=\text { strongly agree }\end{array}$} \\
\hline & 1 & 2 & 3 & 4 & 5 \\
\hline $\begin{array}{l}\text { I hold positive perceptions toward inclusive } \\
\text { special education. }\end{array}$ & 1 & 2 & 3 & 4 & 5 \\
\hline $\begin{array}{l}\text { All stakeholders, including staff, students, parents, } \\
\text { and the school community, are aware of my vision } \\
\text { for instruction and learning. }\end{array}$ & 1 & 2 & 3 & 4 & 5 \\
\hline $\begin{array}{l}\text { My vision for instruction and learning coincides } \\
\text { with my district's mission. }\end{array}$ & 1 & 2 & 3 & 4 & 5 \\
\hline $\begin{array}{l}\text { It is evident that the culture of my school has been } \\
\text { shaped by my vision for instruction and learning. }\end{array}$ & 1 & 2 & 3 & 4 & 5 \\
\hline $\begin{array}{l}\text { I provide relevant, meaningful, and applicable } \\
\text { professional development opportunities to staff } \\
\text { that focus best practices in inclusive education. }\end{array}$ & 1 & 2 & 3 & 4 & 5 \\
\hline $\begin{array}{l}\text { I seek guidance from other colleagues or district } \\
\text { administrators when I have questions or concerns } \\
\text { about inclusive special education programs in my } \\
\text { school. }\end{array}$ & 1 & 2 & 3 & 4 & 5 \\
\hline $\begin{array}{l}\text { I do my best to secure funding and/or resources } \\
\text { for teachers to support best practices in inclusive } \\
\text { education. }\end{array}$ & 1 & 2 & 3 & 4 & 5 \\
\hline $\begin{array}{l}\text { I regularly collaborate with stakeholders to discuss } \\
\text { various aspects of the inclusive special education } \\
\text { program in my school. }\end{array}$ & 1 & 2 & 3 & 4 & 5 \\
\hline $\begin{array}{l}\text { I do my best to allow teachers time to collaborate } \\
\text { for the purpose of coteaching. }\end{array}$ & 1 & 2 & 3 & 4 & 5 \\
\hline $\begin{array}{l}\text { I attend IEP meetings for all students with } \\
\text { disabilities in my school. }\end{array}$ & 1 & 2 & 3 & 4 & 5 \\
\hline $\begin{array}{l}\text { I monitor student assessment data, including data } \\
\text { for students with disabilities, to ensure they are } \\
\text { making appropriate academic progress. }\end{array}$ & 1 & 2 & 3 & 4 & 5 \\
\hline
\end{tabular}

Figure 1. Roles and Responsibilities Associated With Inclusive Education. This survey was created based on findings from Bass (1985), Cobb (2015), Lasky and Karge (2006), Praisner (2003), and Romanuck Murphy (2017). IEP = individualized education plan. 


\begin{tabular}{|c|c|c|c|c|c|}
\hline \multirow{2}{*}{$\begin{array}{l}\text { Transformational Leadership Traits } \\
\text { I consistently provide individualized support to } \\
\text { staff members, depending on their needs. }\end{array}$} & \multicolumn{5}{|c|}{$\begin{array}{c}\text { Key } \\
1 \text { = strongly disagree, } 2=\text { disagree, } 3=\text { neutral, } 4= \\
\text { agree, } 5=\text { strongly agree }\end{array}$} \\
\hline & 1 & 2 & 3 & 4 & 5 \\
\hline $\begin{array}{l}\text { I use a variety of methods to support teachers, } \\
\text { which may include mentorship, coaching, } \\
\text { observations, and professional development. }\end{array}$ & 1 & 2 & 3 & 4 & 5 \\
\hline $\begin{array}{l}\text { I use language that inspires others to achieve the } \\
\text { school's vision for instruction and learning. }\end{array}$ & 1 & 2 & 3 & 4 & 5 \\
\hline I lead by example. & 1 & 2 & 3 & 4 & 5 \\
\hline $\begin{array}{l}\text { I challenge staff to think about old problems in } \\
\text { new ways. }\end{array}$ & 1 & 2 & 3 & 4 & 5 \\
\hline I ask questions that evoke better ideas from staff. & 1 & 2 & 3 & 4 & 5 \\
\hline $\begin{array}{l}\text { I am trusted and respected within my } \\
\text { organization. }\end{array}$ & 1 & 2 & 3 & 4 & 5 \\
\hline Teachers feel comfortable asking for my advice. & 1 & 2 & 3 & 4 & 5 \\
\hline $\begin{array}{l}\text { I instill leadership in others by seeking } \\
\text { opportunities for them to develop their leadership } \\
\text { skills. }\end{array}$ & 1 & 2 & 3 & 4 & 5 \\
\hline $\begin{array}{l}\text { I depend on my values and vision to guide the } \\
\text { decisions I make. }\end{array}$ & 1 & 2 & 3 & 4 & 5 \\
\hline
\end{tabular}

Figure 2. Transformational Leadership Traits Related to Successful Inclusive Education Programs. The survey was created based on the findings from Bass (1985) and Canadian Organizational Behaviour (2017).

\section{Tip 9: Take Action With Practical Strategies to Support Inclusive Education Programs}

School leaders who have reviewed key definitions and concepts associated with inclusive education and have reflected upon their perceptions, roles, responsibilities, strengths, and needs as transformational special education leaders may implement a variety of practical strategies to support inclusive education programs in their schools. Next is a list of practical strategies school leaders can implement to improve upon inclusive special education programs in their schools.

\section{Practical Strategy 1: Reflect on Perceptions Toward Inclusion}

Many studies show school leaders' positive perception toward inclusive education is a strong indicator that inclusive educational programming will be successful (Bublitz, 2016; Chandler, 2015; Hack, 2014). Therefore, school leaders should spend time reflecting upon their honest perceptions toward inclusive education. School leaders may ask themselves if their perceptions toward inclusive education are positive or negative. They may consider their perceptions regarding the benefits and 
challenges of inclusive education for students with and without disabilities. If school leaders' perceptions toward inclusion are negative, they may write them down and reflect upon why they hold these feelings toward inclusive education. Another question to ask may be this: Are these thoughts true, or are they skewed? Either way, school leaders should seek to gain insight into their paradigms by writing them down.

\section{Practical Strategy 2: Identify Strengths, Needs, and Solutions}

School leaders across the nation list a variety of barriers to providing quality inclusive education services, including a lack of training, lack of budget and time, and limited staff (Abernathy, 2012; Ball \& Green, 2014; Praisner, 2003; Romanuck Murphy, 2017; Williams, 2015). As a practical strategy, school leaders may identify areas of strength and need for the inclusive special education program in their school or district. For each "need" or challenge, school leaders should offer a potential solution. School leaders may ask themselves which of these challenges can be addressed tomorrow and who can be of assistance. If it is a long-term change or challenge (e.g., lack of budget), school leaders may ask themselves what can be done to start the process.

\section{Practical Strategy 3: Collaborate With Special Education Teachers}

It is crucial that school leaders understand pertinent laws and concepts related to inclusive special education. If needed, school leaders may review important definitions and principles related to inclusion by rereading the tips embedded in this article. Additionally, as collaboration is a primary role of transformational school leaders, school leaders may arrange a meeting with their special education teachers (Haager \& Klinger, 2005). School leaders may schedule a meeting with special education teams so special education teachers can talk with them about the strengths and challenges of inclusive special education from their perspectives.

\section{Practical Strategy 4: Locate Professional Development for Staff}

One of the primary roles of school leaders is to provide professional development to staff (Earley \& Bubb, 2004). Therefore, if it is an area of need, school leaders should select professional development that incorporates principles of effective inclusion. School leaders may seek assistance in locating appropriate professional development by contacting their special education director or other colleagues. Practitioner journals also offer evidence-based and practical strategies for educators.

\section{Practical Strategy 5: Locate Professional Development to Address Personal Needs}

School leaders are responsible for providing professional development to staff. However, they are also responsible for seeking out professional development to address their own needs. Inclusion is a district-wide effort, and school leaders should use their resources, including colleagues, to find appropriate training or activities to address their needs (Bublitz, 2016). School leaders who would like to improve upon their special education leadership skills may choose to expand their knowledge and skills by subscribing to a special education publication. Alternatively, school leaders may ask their special education director if their district already has access to a subscription.

\section{Practical Strategy 6: Create a Training for Other School Leaders}

As previously noted, one of the primary responsibilities of school leaders is to provide quality instructional leadership and professional development pertinent to inclusive education (Bublitz, 2016; Lynch, 2012). School leaders may develop a brief training for other leaders in their districts, as guided by the information presented in this article. Teaching other school leaders about their roles and responsibilities as transformational leaders who oversee inclusive special education programs 
allows school leaders to learn the material twice. They learn the materials by reviewing this article, and they learn it again, but at a deeper level, by developing their own training for others.

\section{Practical Strategy 7: Attend Teacher Professional Learning Community Meetings}

Haager and Klinger (2005) suggested collaboration is necessary to maintain a culture of inclusion. School leaders collaborate with multiple stakeholders to create and sustain effective inclusive education models (Satterwhite, 2015). General education teachers and special education teachers provide invaluable insight into the reality of inclusive special education programs. Therefore, if school leaders are not already doing so, they may attend teachers' professional learning community meetings. School leaders should actively listen, ask questions, and strive to learn all they can from these meetings. To foster communication, school leaders may ask teachers about their celebrations and struggles to gain a better understanding of the reality of inclusive special education in their schools.

\section{Practical Strategy 8: Create Leadership Goals Based on Strengths}

School leaders should take time to identify areas of strength and need from the surveys provided in Figures 1 and 2. School leaders may focus on one strength they can build upon. Based upon this strength, school leaders may set themselves a weekly or monthly goal with specific action steps that will allow them to build on this skill. School leaders might ask themselves why these particular goals are important to them. A guiding question might ask how accomplishing these goals will help to make them more effective special education leaders and school leaders overall.

\section{Practical Strategy 9: Create Goals Based on Leadership Needs}

After identifying an important strength, school leaders should identify one area of need, guided by the surveys provided in Figures 1 and 2. Based on that need, school leaders may write themselves a time-bound goal that includes action steps to meet that goal. For example, when considering one's transformational leadership strengths and needs, a school leader might realize that her ability to provide intellectual stimulation to staff members has been lacking. The school leader may observe that teachers are not using best practices in inclusive education. However, it is noted that the necessary professional development in this area has not been provided to staff. Therefore, the school leader may write the following personal goal: By February 1, professional development for staff that focuses on effective coteaching strategies will be located. This training will be delivered at the staff meeting scheduled for February 12. The information presented in the training will be considered when completing classroom observations and providing feedback to staff.

\section{Practical Strategy 10: Use the Coteaching Observation Checklist}

School leaders can use the information presented in Tip 3 to review the six coteaching models of instruction. Using the information presented in Tip 3, school leaders may observe a cotaught lesson in their school. The results may be used to provide feedback to teachers based on observations from the session. School leaders can then set goals together with teachers to enhance future cotaught lessons. Progress, in terms of coteaching efficacy, should be discussed in a follow-up session.

\section{Practical Strategy 11: Get Involved in Professional Organizations}

School leaders can provide a voice that advocates for services and funding for resources that support education, including inclusive special education programs. Change in education does not happen passively, and leaders' involvement and commitment to professional organizations, at both local and national levels, aids in fostering positive change in schools. There is a variety of professional 
organizations and grant opportunities available to public schools, many of which are accessible by conducting a simple Internet search.

\section{Final Thoughts}

The aim of this article was to provide school leaders with knowledge, skills, and practical strategies to sustain or improve upon effective inclusive special education programs in their schools. As a result of the materials presented in this article, school leaders should now understand the pertinent definitions, laws, and concepts associated with inclusion; models of coteaching; transformational leadership theory and traits; roles and responsibilities of school leaders in inclusive education programs; and practical strategies to implement to improve upon current inclusive education practices. This article was designed to provide role clarity and to support school leaders in becoming the most effective special educational leaders they can be through the use of transformational leadership traits.

No matter school leaders' current experience and expertise as special education leaders, there are steps they can take to transform inclusive education in their schools. School leaders, as special education leaders, have the power to truly transform and influence special education in their schools. School leaders are one of the largest influencers of how successful or unsuccessful inclusive special education programs will be in their schools. School leaders have the power to influence the vision, mission, culture, climate, and values of their schools. If school leaders continue to build their transformational leadership skills to best meet the needs of all students, they can influence a culture of acceptance, love, open-mindedness, and caring between students, staff, parents, and the community.

\section{References}

Abernathy, F. D. (2012). Assessing the attitudes of administrators to include students with disabilities. Retrieved from ProQuest Dissertations and Theses Global. (1221263884)

Ball, K., \& Green, R. L. (2014). An investigation of the attitudes of school leaders toward the inclusion of students with disabilities in the general education setting. National Forum of Applied Educational Research Journal, 27, 57-76.

Bass, B. M. (1985). Leadership and performance. New York, NY: Free Press

Bonar, R. I., Jr. (2000). The effect of leadership behaviors on employee commitment, satisfaction, and strength of culture. Retrieved from ProQuest Dissertations and Theses Global. (304678469).

Bublitz, G. (2016). Effective strategies for district leadership to create successful inclusion models: Special education directors and school reform in context of least restrictive environment. Retrieved from ProQuest Dissertations and Theses Global. (1804049365)

Canadian Organizational Behaviour. (2017). Self-assessment: What are your transformational leadership tendencies? Retrieved from http://highered.mheducation.com/sites/1259030539/student_view0/chapter12/selfassessment_what_are_your_transformational_leadership_tendencies_.html

Carson, C. (2015). Rethinking special education's "least restrictive environment." Michigan Law Review, 113, 1397-1426.

Chandler, T. L. (2015). School principal attitudes toward the inclusion of students with disabilities. Retrieved from ProQuest Dissertations and Theses Global. (1651236077)

ChangingMinds.org. (n.d.). Leadership theories. Retrieved from http://changingminds.org/disciplines/leadership/theories/leadership_theories.htm 
Cobb, C. (2015). Principals play many parts: a review of the research on school principals as special education leaders 2001-2011. International Journal of Inclusive Education, 19, 213-234. doi:10.1080/13603116.2014.916354

Earley, P., \& Bubb, S. (2004). Leading and managing continuing professional development: Developing people, developing schools. London, United Kingdom: Sage.

Garrick Duhaney, L. M., \& Salend, S. J. (2000). Parental perceptions of inclusive educational placements. Remedial \& Special Education, 21, 121.

Haager, D. S., \& Klingner, J. K. (2005). Differentiating instruction in inclusive classrooms: The special educator's guide. Boston, MA: Allyn \& Bacon.

Hack, A. J. (2014). Pennsylvania middle school principals' attitudes toward the inclusion of students with disabilities in the regular education classroom. Retrieved from ProQuest Dissertations and Theses Global. (1650670597)

Harpell, J. V., \& Andrews, J. J. W. (2010). Administrative leadership in the age of inclusion: Promoting best practices and teacher empowerment. The Journal of Educational Thought, 44, 189-210.

Individuals With Disabilities Education Improvement Act (IDEA) of 2004, 20 U.S.C. $§ 1400$ (2004).

Ko, B., \& Boswell, B. (2013). Teachers' perceptions, teaching practices, and learning opportunities for inclusion. Physical Educator, 70, 223-242.

Kurth, J., \& Mastergeorge, A. M. (2010). Individual education plan goals and services for adolescents with autism: Impact of age and educational setting. Journal of Special Education, 44, 146160. doi:10.1177/0022466908329825

Lashley, C. (2007). Principal leadership for special education: An ethical framework. Exceptionality, 15, 177-187. doi:10.1080/09362830701503511

Lasky, B., \& Karge, B.D. (2006). Meeting the needs of students with disabilities: Experience and confidence in principals. NASSP Bulletin, 90, 19-36.

Lucas, S. E., \& Wayne, V. J. (2003). Transformational leadership: Principals, leadership teams, and school culture. NASSP Bulletin, 87, 85.

Lynch, J. M. (2012). Responsibilities of today's principal: Implications for principal preparation programs and principal certification policies. Rural Special Education Quarterly, 31, 40-47. doi:10.1177/875687051203100205

Marks, H. M., \& Louis, K. S. (1997). Does teacher empowerment affect the classroom? Teachers' work and student experiences in restructuring schools. American Journal of Education, 107, 532-575. doi:10.1086/444197

Marzano, R. J., Waters, T., \& McNulty, B. A. (2005). School leadership that works. Alexandria, VA: Association for Supervision and Curriculum Development.

Moman Basham, L. (2012). Transformational and transactional leaders in higher education. SAM Advanced Management Journal, 77, 15-37. doi:10.19030/jier.v8i4.7280

National Center on Educational Restructuring and Inclusion. (1994, June). National study of inclusive education. Retrieved from http://files.eric.ed.gov/fulltext/ED375606.pdf

Nicolas, A. (2015). The role of the principal in successfully shaping school culture: A basic qualitative study. Retrieved from ProQuest Dissertations and Theses Global. (1668379440)

Papillion La Vista Community Schools. (2017). Co-teaching and in-class support observation guide. Papillion, NE: Author. 
Praisner, C. (2003). Attitudes of elementary principals toward the inclusion of students with disabilities. Council for Exceptional Children, 69, 135-145. doi:10.1177/00144029030690201

Romanuck Murphy, C. D. (2017). Educational leaders and inclusive education: Perceptions, roles, and responsibilities (Unpublished doctoral dissertation). Department of Education, Trident University International, Cypress, CA.

Salisbury, C. L. (2006). Principals' perspectives on inclusive elementary schools. Research \& Practice for Persons With Severe Disabilities, 31, 70-82. doi:10.2511/rpsd.31.1.70

Satterwhite, L. L. (2015). Teachers' and administrators' attitudes towards inclusion. Retrieved from ProQuest Dissertations and Theses Global. (1695831430)

Stevenson-Jacobson, R. J., \& Hilton, A. (2006). Principals' perceptions of critical skills needed for administration of special education. Journal of Special Education Leadership, 19, 39-47.

Tucker, B. A., \& Russell, R. F. (2004). The influence of the transformational leader. Journal of Leadership and Organizational Studies, 3, 1-5.

U.S. Department of Education. (2010). Free and appropriate public education for students with disabilities: Requirements under section 504 of the Rehabilitation Act of 1973. Retrieved from https://www2.ed.gov/about/offices/list/ocr/docs/edlite-FAPE504.html

U.S. Department of Education. (2013, August). Characteristics of public and private elementary and secondary school principals in the United States: Results from the 2011-2012 schools and staffing survey. Retrieved from http://nces.ed.gov/pubs2013/2013313.pdf

Urton, K., Wilbert, J., \& Hennemann, T. (2014). Attitudes towards inclusion and self-efficacy of principals and teachers. Learning Disabilities, 12, 151-168.

Waldron, N. L., \& McLeskey, J. (1998). The effects of an inclusive school program on students with mild and severe learning disabilities. Exceptional Children, 64, 395-405. doi:10.1177/001440299806400308

Williams, J. M. (2015). Attitude and perceptions of public school principals in Illinois toward inclusion of students with disabilities in the general education classroom. Retrieved from ProQuest Dissertations and Theses Global. (1680274240)

Yssel, N., Engelbrecht, P., Oswald, M. M., Eloff, I., \& Swart, E. (2007). Views of inclusion: A comparative study of parents' perceptions in South Africa and the United States. Remedial \& Special Education, 28, 356-365. doi:10.1177/07419325070280060501

Zohar, D., \& Tenne-Gazit, O. (2008). Transformational leadership and group interaction as climate antecedents: A social network analysis. Journal of Applied Psychology, 93, 744-757. doi:10.1037/0021-9010.93.4.744 
The Journal of Educational Research and Practice provides a forum for studies and dialogue that allows readers to better develop social change in the field of education and learning. Journal content may focus on educational issues of all ages and in all settings. It also presents peer-reviewed commentaries, book reviews, interviews of prominent individuals, and additional content. The objectives: We publish research and related content that examines current relevant educational issues and processes aimed at presenting readers with knowledge and showing how that knowledge can be used to impact social change in educational or learning environments. Additional content provides an opportunity for scholarly and professional dialogue regarding that content's usefulness in expanding the body of scholarly knowledge and increasing readers' effectiveness as educators. The journal also focuses on facilitating the activities of both researcher-practitioners and practitioner-researchers, providing optimal opportunities for interdisciplinary and collaborative thought through blogging and other communications.

Walden University Publishing: http://www.publishing.waldenu.edu 